\title{
Comparison the effectiveness of psychodrama and cognitive group therapy and combination of both on depression and help seeking in hospitalized patients with major depression
}

\author{
Faezeh Es' ${ }^{\prime}$ aghi ${ }^{1}$, Farshad Bahari $^{2}$ \\ 1-MSc Clinical Psychology, Tehran University of scientific research, Tehran, Iran (Corresponding Author ). \\ ORCID: 0000-0002-4564-8455 E-mail: f.eshaghi_psy@yahoo.com \\ 2-Assistant Professor, Department of Counseling, Arak Azad University, Arak, Iran. ORCID: 0000-0003-3431- \\ 6380
}

Received: 07/10/2018

Accepted: 03/02/2019

\begin{abstract}
Introduction: Depression is one of the most common psychiatric disorders that will become the world's second largest by 2020.

Aim: To compare the effects of psychodrama and cognitive group therapy and their combination on depression and purpose of seeking admission among patients with major depression.

Method: The study was a quasi-experimental study with pre-test and post-test and with control and experimental group. The statistical population of the study was major depressive patients (Razi and Lavasani Hospitals in Tehran). 40 patients were selected randomly and were randomly assigned into three groups. Twelve sessions of intervention were held according to the classical psycho-pacific protocol and Frei's cognitive therapy group. Beck Depression Inventory (2007) and Cohen Coaching Inventory Questionnaire (2012) were applied to them. In the analysis of data, one-variable covariance analysis and Tukey's post hoc test were used.
\end{abstract}

Results: There were significant differences between the three groups in depression scores and amortization intention ( $\operatorname{sig}<0.001)$.

Conclusion: The findings showed that all three interventions were effective in decreasing the rate of depression and increasing the level of intention seeking, but cognitive group therapy was more effective in decreasing depression and psychodrama.

Keywords: Psychodrama, Cognitive group therapy, Depression, Help seeking intention

How to cite this article : Es' haghi F, Bahari F. Comparison the effectiveness of psychodrama and cognitive group therapy and combination of both on depression and help seeking in hospitalized patients with major depression. Shenakht Journal of Psychology and Psychiatry. 2019; 6 (1): 107-124.URL :http $/ / /$ shenakht.muk.ac.ir/article-1-547-fa.pdf 


\section{مقايسه اثربخشى روان نمايشكرى و كروهدرمانى شناختى و تركيبى از اين دو بر افسر دكى و قصد استمداد طلبى بيماران افسر ده بسترى}

فائزه اسحاقى '، فرشاد بهارى'

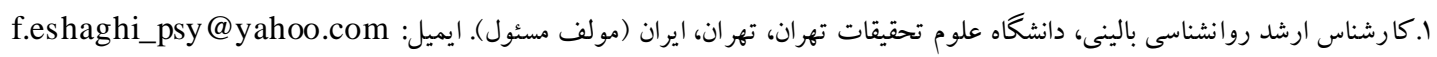

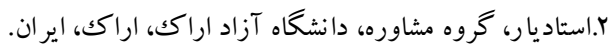

مقدمه: افسرد گى، از شايعترين اختلالات روانى است كه تا سال ·r.r. به رتبه دوم جهانى تبديل مىشود. هدف: مقايسه تأثير سايكودرام و گروه درمانى شناختى و تركيب اين دو بر ميزان افسردگى و قصد استمداد طلبى بيماران مبتلا به افسردگى عمده بسترى انجام شد.

روش: نوع مطالعه شبه آزمايشى با بيش آزمون و پِ آزمون و همراه با گروه آزمايش و كترل بود. جامعه آمارى بيماران بسترى

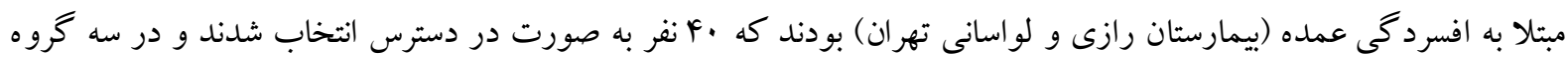

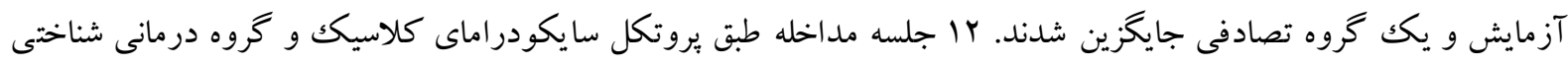

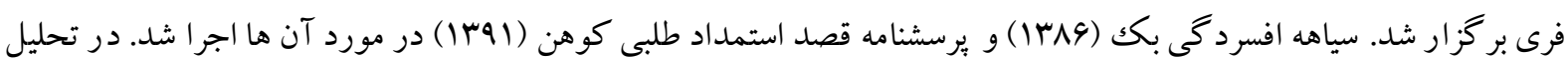
داده ها از تحليل كواريانس تكك متغيره و آزمون تعقيبى توكى استفاده شد.

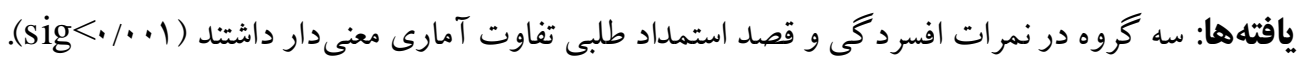
نتيجه كيرى: يافته ها نشان داد كه هر سه مداخله در كاهش ميزان افسردگى و افز ايش ميزان قصد استمداد طلبى مؤثر بودهاند اما

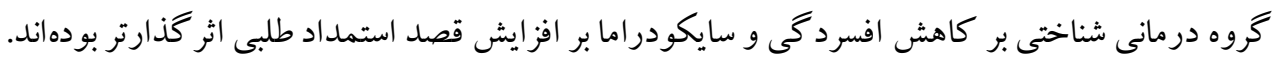
كليد وازهها: سايكودراما، گروه درمانى شناختى،افسردگى،قصد استمداد طلبى 


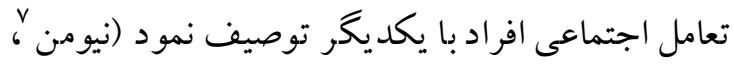

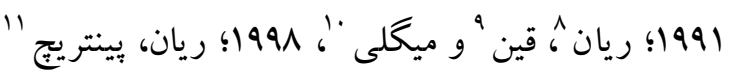

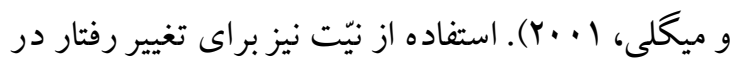
مسائل جدى مانند التيام و افسردگى و فقدان، سابقه طولانى در روان شناسى دارد. در حقيقت استمداد طلبى مانى اصطلاحى است كه معمو لاً براى اشاره به رفتار فعالانه جستجو و يارى طلبى از افراد ديخر به كار رفته است

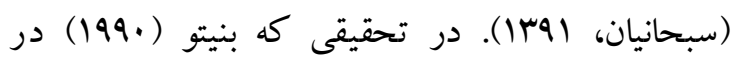
حوزه افسردگى و قصد استمداد طلبى انجام داد نتيجه كرفت كه بسيارى از مردم به دنبال كمككهاى حرفهاى و نمى آيند و اين باعث افسردگى در آن ها مى شود بنابراين بايد از مداخلاتى سود جست كه به به فرد اين اين جرأت را بدهد تا درمان شود. در اين ميان شناخت درمانى (C.T) شناسايى و به جالش كشيدن تفكرات شخص است، براى درمان بسيارى از مشكلات روان شناختى و و اختلالات روانيزشكى، از كنترل خشم و اختلالات

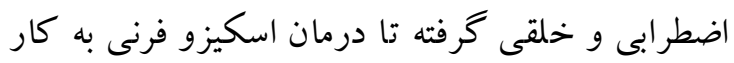
مى رود. يافتهاى علمى متعددى كه طى اين سال ها به دست آمده كه شناخت درمانى را به عنوان روشى لئى كارآمد در درمان براى بسيارى از مشكلات روان

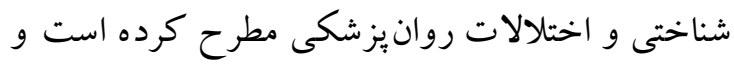
در برخى مو ارد مانند افسردگى عمده، بهعنوان درمان

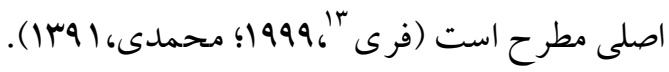

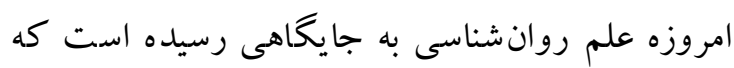
مى تواند از ابزارهاى هنرى مانند نمايش جهت روت ارتقاء

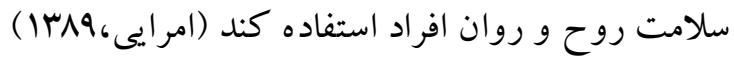

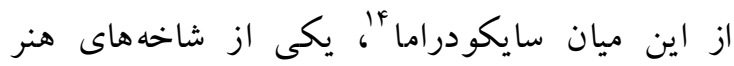

\section{مقلمهd}

سلامت روانشناختى يكى از مسائل مطرح در دنياى امروز است كه در كانون توجّه يُزوهشخران قرار كرفته

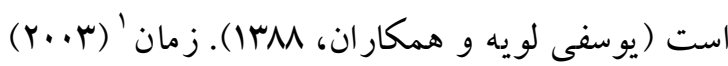
سلامت روانى را به عنوان تو انايى فرد در غلبه بر موانع

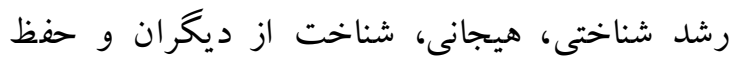
روابط اجتماعى تعريف مى كند.

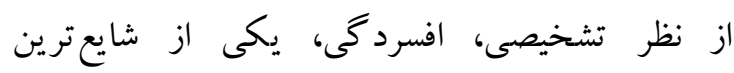

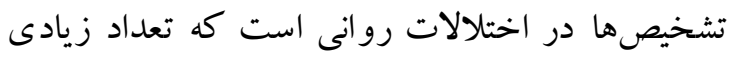
از افر اد، با سوابق مختلف را شامل مى شود و كسترشى اختى

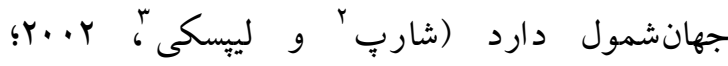

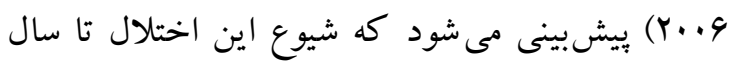
r.r.r.

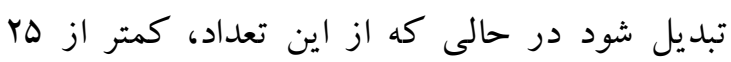
درصد به درمان هاى مؤثر دسترسى خو اهند داشت لهن

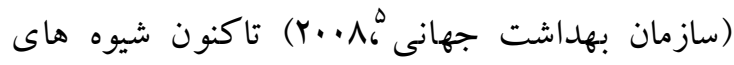
مختلفى براى درمان افسر دگى ارائه شده است. از طرفى ديخر يكى از عوامل مهمى كه در روابط درمال اجتماعى و ايجاد سلامت روان، نقش مهمى در فرد دارد و يكى از راه كارهاى آدمى در مقابل با مسائل

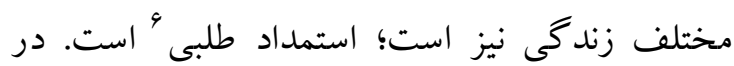
جريان استمداد طلبى مسائلى قابل تو جه است كه در جريان آن اولاً فرد مشكل يا نيازى دارد كه خودش نمى تو اند آنها را رفع كند. دوم اينكه، مشكل به كونه اى است كه با تلاش بيشتر و بهره گيرى از ساير منابع استمدادى كاهش مى يابد. سوم اينكه، فرد نيازمند كمك به شيوهاى مستقيم از فرد ديخر استمداد

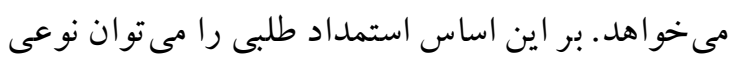

${ }_{1}^{1}$ Zeman
${ }_{2}^{2}$ Sharp
${ }^{3}$ Lipsky
${ }^{4}$ Lambert
${ }^{5}$ WHO
${ }^{6}$ Help-Seeking


الهr|) از آن سو در سايكودراما كه مىتوان آن را نوعى مكتب التقاطى به حساب آورد سعى مى شود تا

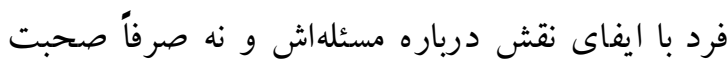
كردن درباره آن به تخليه هيجانى دست يابد كه موجب دربه بهبودى و شفاى مراجع مى شود. با اين وجود آزاد سازى احساس و خود ادراكى به تنهايى عاملى براى ايجاد تغييرات در شيوه تفكر نمى شود به همين جهت

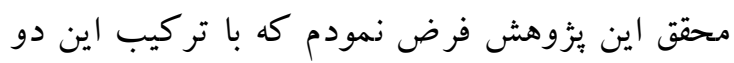
رويكرد درمانى مى توان خلأ رفتارى همراه با تخليه هيجانى را در شناخت درمانى گروهى و شناخت و ورك تفكر را در سايكودراما، برطرف نمايم و هم به جهت

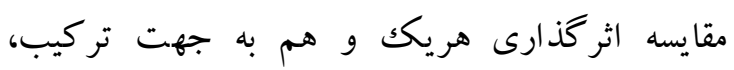

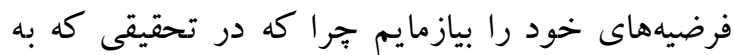
تركيب اين دو برداخت رويكرد شناختى رفتارى (نه

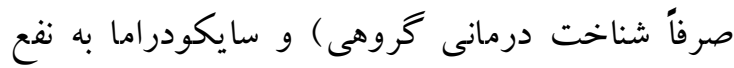
رويكرد شناختى رفتارى با هم تركيب شده اند و نتايج اثر گذارى به دست آورده اند به طور مثال طبق تحقيق

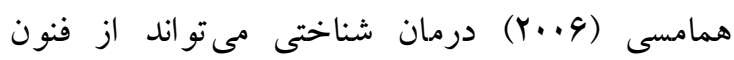

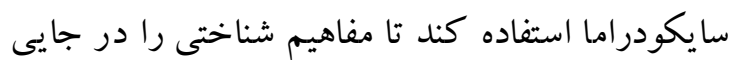
كه به دست آوردن توضيحات كلامى به افراد موفقيت آميز نيست به شركت كنند كان توصيف كند و ورد

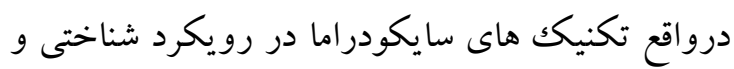
رفتارى مورد استفاده قرار مى گرفت نه سايكودراماى سناى كلاسيك. در واقع تحقيق هما مسى (9.9. مىدهند كه كدام يكك از تكنيك هاى سايكودراما اثربخشى بيشترى در تركيب با رويكرد شناختى و و رفتارى داشته است. بر اساس بررسى و مرور منابع توسط نويسنده مطالعاتى كه به مقايسه گرووه درمانى

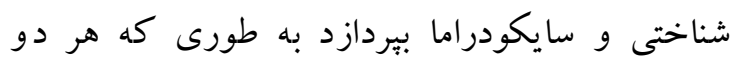
رويكرد با يروتكل كامل انجام شوند بسيار بسيار محلدود بوده است.
درمانى ' كه ديدى متفاوت در حوزه رواندرمانى به شمار مى آيد، به عنو ان يكك ابزار درمانى در اوايل دهه

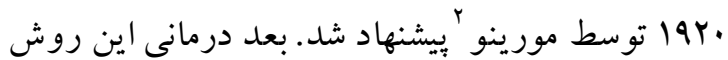

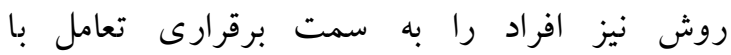

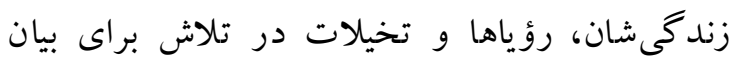
احساسات ابراز نشده، كسب دركك و بينشهاى جديد و تمرين رفتارى سالمتر و جديدتر ترغيب مى كند

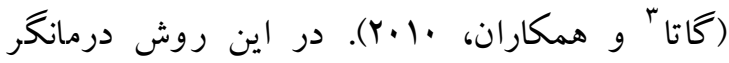
راهكارهاى گروهى را ترتيب مىدهد كه سر انجام آن آكًاه شدن بيمار از نقش اجتماعى خود است. بيمار در جريان نمايش روانى در مى يابد كه هنگام ارتباط با سبا محيط بيرامون و روابط بين فردى و اجتماعى بهتر است

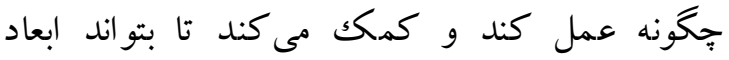
روانشناختى خودش را كشف كند (آدام بلانر/حق بق بـ شناس و اشكانى،rیr| روش ها و مفاهيم سايكودراما انعطاف يذير و توانايى انطباق با محدوده وسيعى از مدلها و درمانهاى روان شناسى را دارد. اين روش درمانى هم طبق تحقيق ميرزايى و رياحى (rar) بر روى اختلالات بالينى به ويزه اختلال هاى خلقى اثربخشى خودش را نشان داده است. نظريه شناختى و روان نمايشكرى دود رونس نظريه روان روان

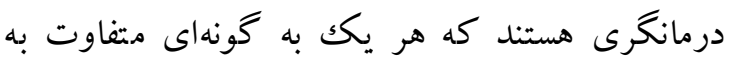
تبيين و توصيف مسائل و مشكلات روانشناختى افراد

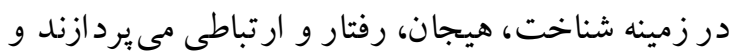
راهبردهاى منحصر به فردى را به منظور رفع آنها ارائه

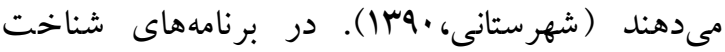
درمانى گروهى، سعى مى شود تا تمامى جنبهاى

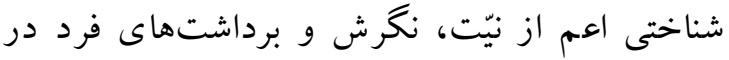

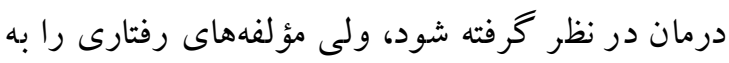
روشنى شامل نمى شود (فرى 1999؛ محمدى وفرنام، 
با توجه به آنجهه كفته شد، هدف از اين يثزوهش مقايسه ابزار

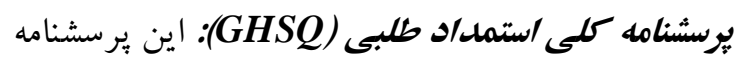

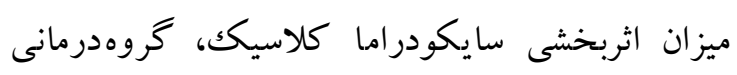

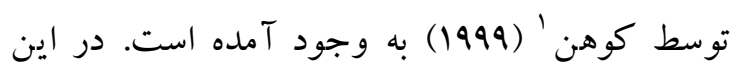
بر سشنامه از يكك قالب ماتريسى استفاده شد كه مىتوان آن راطبق هدف و نياز تغيير داد. اين برسشنامه توسط ئرس بهارى (|l|r|) ترجمه شده است پاسخ ها به صورت

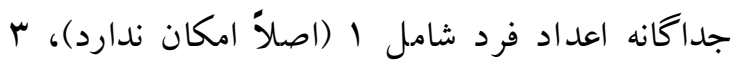
(امكان ندارد)، ه (احتمال دارد)، V (كاملاً احتمال شناختى و تركيبى از اين دو بر افسردگى و قصد آتردي

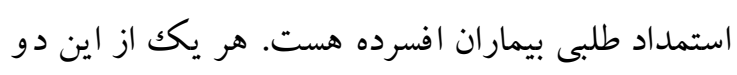

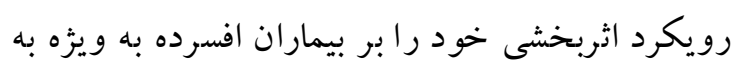

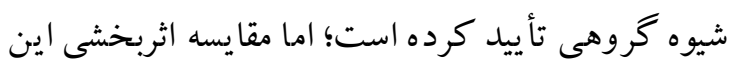
دو و حتى صرفاً تركيب اين دو مى تواند نتايج قابل تأملى داشته باشد.

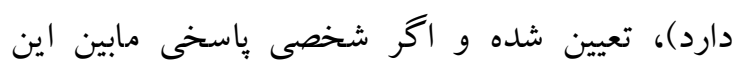

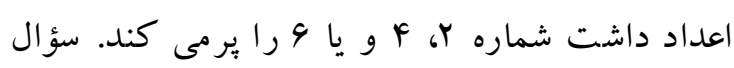
آخر متعلق به كسانى است كه مايل اند از غير از كسانى كه در جدول وجود دارند، استمداد بطلبند كه در آنس جدول به آن اشاره شده است. در همه سؤالات آيتمهاى اندازهگيرى انخيزه استمداد طلبى داده شده

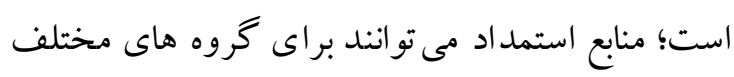

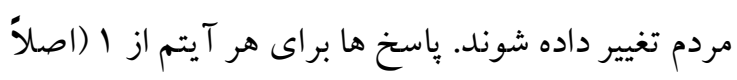

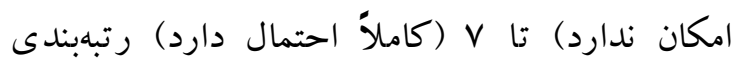

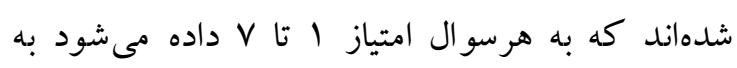
صورتى كه باسخ ل، يُك نمره و به باسخ V، هفت نمره

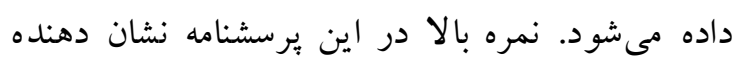

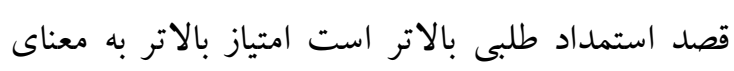

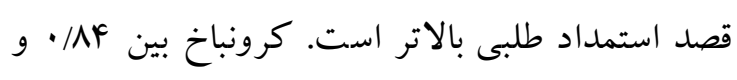

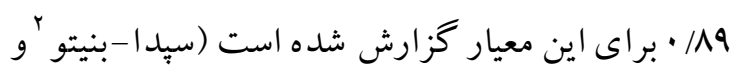

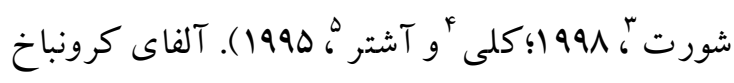

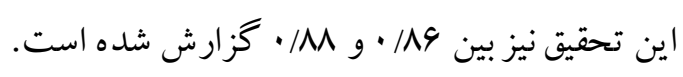

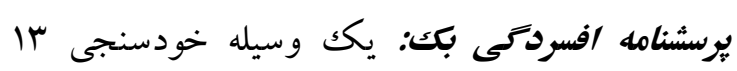

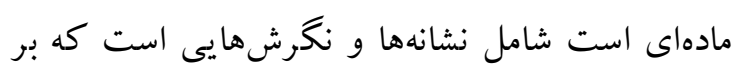
حسب شدّت در جهبندى شدهاند. هر ماده سؤال داراى

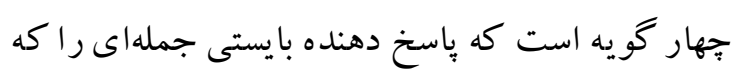

\footnotetext{
${ }^{1}$ Cohen

${ }^{2}$ Cepeda-Benito

${ }^{3}$ Short

${ }^{4}$ Kelly
} روش بزوهش حاضر نيمه تجربى با طرح بيش آزمون،

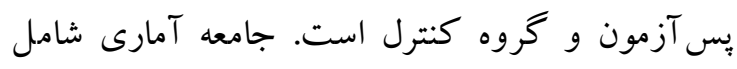
كليه بيماران مرد مبتلا به افسرد گى اساسى بسترى شده

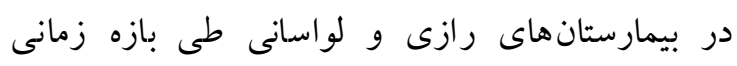

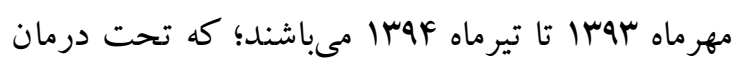
دارويى قرار داشتند. نمونه آمارى بيماران بسترى مبتلا به افسردگى عمده (بيمارستان رازى و لواسانى تهران)

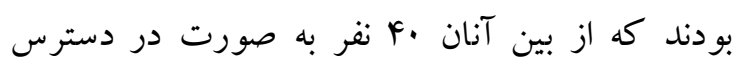

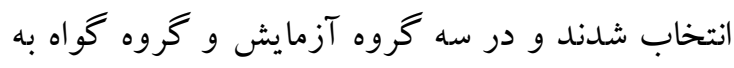
صورت جايخزينى تصادفى قرار گرفتند حجم نمونه با

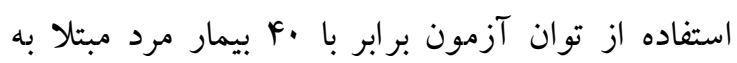

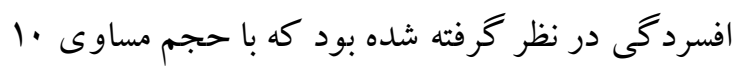

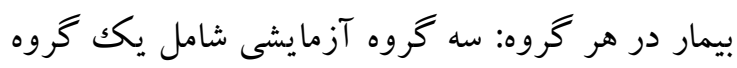

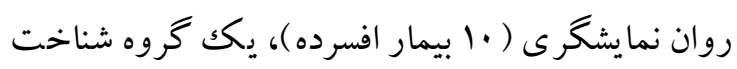
درمانى گروهى ( •ا بيمار افسرده)، يكى گرووه تر كيبى

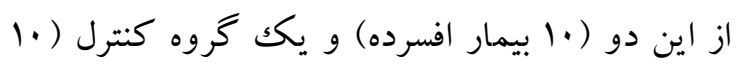
بيمار افسرده) به صورت تصادفى جايخزين شدند. هر آنر

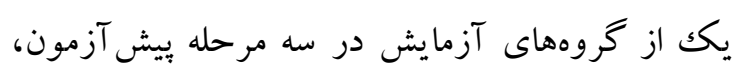

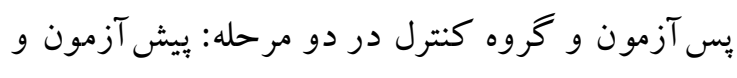

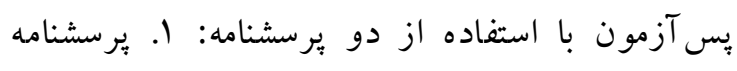

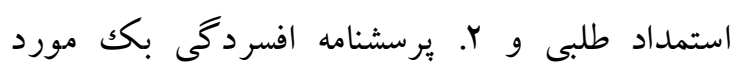
آزمون و ارزيابى قرار گرفتند. 
كار با افراد گرووه آزمايش تركيب سايكودرام و گروه

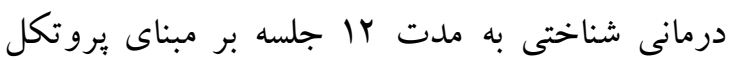

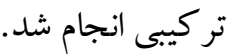
معيار اصلى ورود عبارت بود از ا. آزمودنى تشخيص افسردگى عمده دريافت كرده باشد و با توجه به سياهه

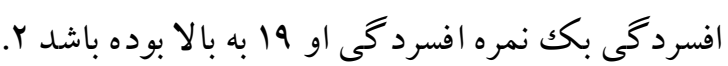
حداقل يكك هفته از بسترى او در مرحله حاد كذشته باشد.r. از سواد خواندن و نوشتن برخوردار باشند. معيار خروج عبارت بودند از: ا. آزمودنى اختلالات همراه ديكرى از جمله اختلالات محور دو اختصاصاً

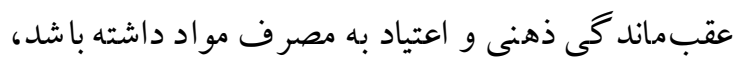

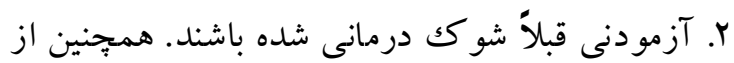

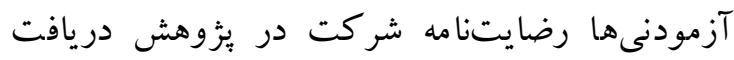
كرديد. روش تجز يه و تحليل داده ها: بـ از تكميل برسش نامه ها توسط نمونه ها به صورت بيش آزمون و پس بس آزمون،

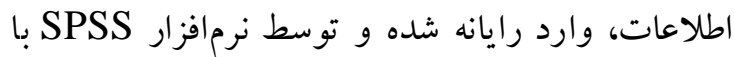
استفاده از آزمونهاى مورد نياز تجزيه و تحليل خواهند شد و يافته ها به صورت جداول و نمودارهاى توضيحى له تهري و استنباطى تفسير خواهند گرديد. در اين يزوهش براى

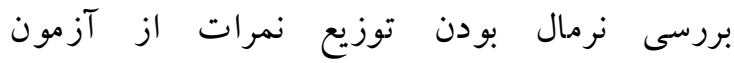
كولمو گروف - اسميرنوف و شابير و - ويلكك استفاده شد و همجنين بر اي برر سى مفروضه بر ابرى واريانس ها

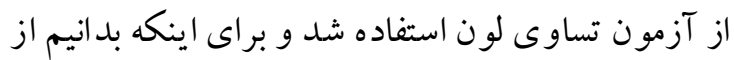
بين سه مداخله در سه گروه متفاوت كدام يـك اثربخشى بيشترى داشته از آزمون تعقيبى توكى استفاده

اطلاعات جمعيت شناختى: در اين بُزوهش تمامى نمونهها از بين مردان انتخاب شده است. •^ درصد از شركت كنندگان مجرد و r ب درصد متأهل بودند و و

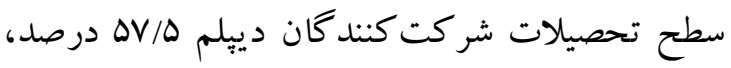

با وضعيت فعلى وى مناسبتر است انتخاب نما يد. اين

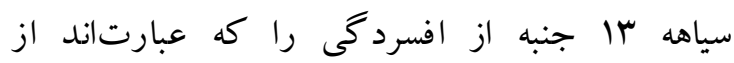
غمخينى، بدبينى، احساس شكست، نارضايتى، گُناه، بيزارى از خود ، خود آزارى، كنارهگيرى، بـ تصميمى، تغيير در خود بِنداره، دشوارى در كار، احساس خستخى و بى اشتهايى ارزيابى مى كند. به منظور تعيين

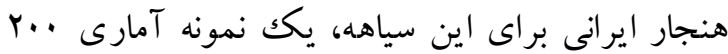
نفرى از جمعيت دانشجويى با روش تصادفى از بين دانشجويان دانشكدهاى تهران انتخاب و و مورد آزمون گرى واقع شده است (منصور و دادستان،

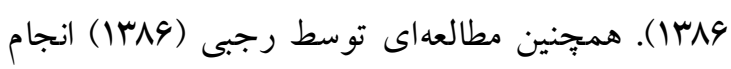
كرفت كه وى ضريب آلفاى كلى و به روش توصيف

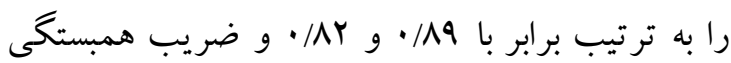

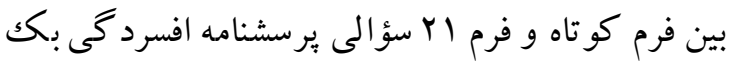
19VI) • محاسبه كرد.

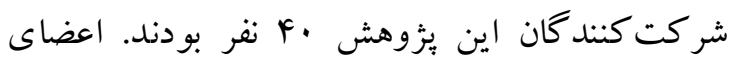
كروههاى آزمايش در با جلسه •9 دقيقهاى هر كروه به طور مجزا در جلسه هاى روانهاى نمايشخرى،

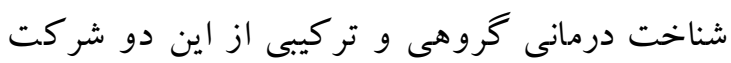

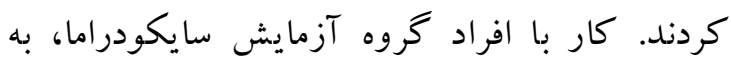
صورت گروهى به مدت آ جات جلسه، بر مبناى اصول اصلى سايكودرام طراحى و اجرا شد. در اين مطالعه جهت افزايش اثربخشى سايكودرام و همجنين قوانين بيمارستان جلسات هر روز برگزار گرديد. اجراى

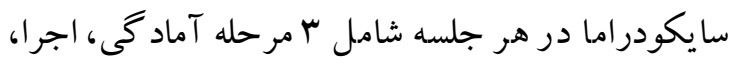
تمرين رفتارى و مشاركت و اختتام بود. در اين مطالعه بيشترين زمان صرف شده به مرحله آخر يعنى تمرين رفتارى اختصاص داده شد.

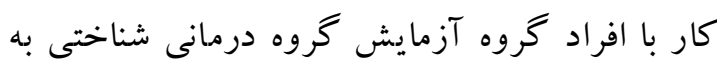
صورت گروهى به مدت إ جلسه بر مبناى بروتكل كروهدرمانى شناختى مايكل فرى انجام شد. 
جدول ا ميانكين و انحراف استاندارد يِيش آزمون - يّآزمون مقياس افسردكى و استمد اد طلبى در بين كروههاى آزمايش و كنترل (n=r)

\begin{tabular}{|c|c|c|c|}
\hline ِسآزمون & ييشآزمون & مرحله & متغير هاى يخوهش \\
\hline ميانگين & ميانخين (انحراف استاندارد) & كروه ها & \multirow{5}{*}{ افسرد } \\
\hline$r \cdot / r V(r T / Y)$ & $(. r / 9) \& q / \Gamma r$ & سايكودرام & \\
\hline KN/YQ(YT/F) & $R Q / M r(Y r / q)$ & گروه درمانى شناختى & \\
\hline$Y F / Y \Delta(Y Y / \Lambda)$ & $M Y / Y F(N / F F)$ & تر كيبى از اين دو & \\
\hline$Y Q / 9 \cdot(K Y / F)$ & $Y F / Y V(G / r \cdot)$ & كنترل & \\
\hline $\mid 9 r / \pi r(\mid 1 / Y 1)$ & $\operatorname{IVq/IY(19/IF)}$ & سايكودرام & \multirow{4}{*}{ قصد استمد اد } \\
\hline $1 \wedge r / r \Delta(\Delta F / r Y)$ & $199 / \mathrm{rV}(r \Delta / \cdot r)$ & گروه درمانى شناختى & \\
\hline $\mid \Lambda F / N Y(\Delta F / F F)$ & $\mid \Delta r / F \cdot(r q / 11)$ & تر كيبى از اين دو & \\
\hline$|99 / Y|(\mid F / Y I)$ & IVQ/Yq (Yr/II) & كنترل & \\
\hline
\end{tabular}

نمرات از آزمون شاييرو - -ويلك استفاده شد كه به خاطر معنادار نشدن آن در بيش آزمون و وِ بس آزمون مى توان كفت دادهها از توزيع نرمال برخوردار هستند. براى بررسى همخنى واريانسها از آزمون لون استفاده كرديد كه با توجّه به عدم معنادارى آزمون لون براى بردي بيش آزمون - يس آزمون مى توان نتيجه گرفت كه به بيش فرض همخنى وار يانس ها برقرار است. براى بررسى نبودن تعامل بين گرووهها و نمرات

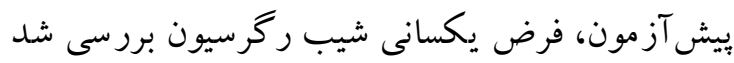
نتيجه اين بررسى نشان داد f محاسبه شده در سطح ه/• ركرسيون در متغير افسردگى يكسان است و بين گروه ها و بيش آزمون تعامل وجو د ندارد.

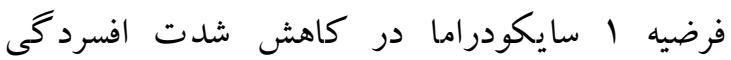
بيماران افسرده بسترى مؤثر است.
براى آزمون فرضيّهاى تحقيق از آزمون تحليل كواريانس تكك متغيره (ANCOVA) استفاده شده آره است. قبل از اجراى آزمون تحليل كواريانس، ييشفرضهاى آن (آزمون كولمو خروف - اسميرنوف يا شاييرو ويلك، آزمون لون، يكسانى شيب ركر سيون،

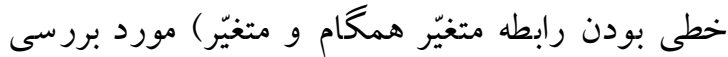

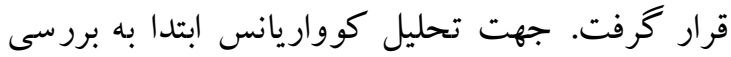
بيش فرضهاى كوواريانس در متغير افسرد گى برداخته مىشود. براى بررسى نرمال بودن توزيع نمرات از آزمون

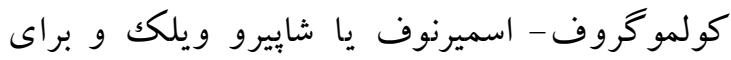
بررسى مفروضه برابرى واريانس ها از آزمون لون استفاده شد كه نتايج اين آزمون نشان مىدهد كه توزيع نمرات متغيّر افسردگى در بِيش آزمون- يس آزمون

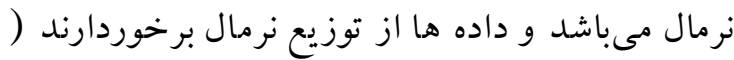

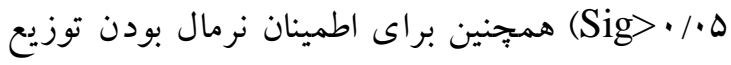




\begin{tabular}{|c|c|c|c|c|c|c|c|}
\hline توان آزمون & اندازه اثر & سطح معنى دارى & $\mathbf{F}$ & مجذانكين & آزادى درجه & مجذوروات & منبع تغييرات \\
\hline .1 .4 & $\cdot 1$ & .1 .9 & $r / \cdot \Delta$ & rVG/rr & 1 & rVG/rr & اثر هميراش \\
\hline \multirow[t]{3}{*}{.$/ 99$} & $\cdot N G$ & $\cdot 1 \cdots \cdot 1$ & $V \cdot M^{F}$ & $\Delta r V / I F A$ & 1 & $\Delta r V / I F \wedge$ & اثر كروه \\
\hline & & & & l & IV & rVG/99 & خطا \\
\hline & & & & & r. & llov. & كل \\
\hline
\end{tabular}

بر سايكودراما در كاهش افسردگى N9 • مؤثر واقع شده است اين بدان معناست كه مداخلات سايكودراما افسردكى را V9/ · تحت تأثير قرار داده است و موجب كاهش آن شده است. با نكاهى به ستون توان آزمون كه مقدار آن 99/ • است (بالاى • • • ) مى توان نتيجه كرفت كه ا. نمونه تحقيق از كفايت برخوردار است ب. اين تأثير گذارى در 99/ · موارد درست است و فقط / • خطا يا امكان نخر فتن نتيجه وجود دارد. فرضيه r Y Yروه درمانى شناختى در كاهش شدت افسردگى بيمار ان افسرده بسترى مؤثر است.
همان طور كه از يافته هاى جدول Y مشخص است با توجه به جدول ميانگينها مشاهده مىشود كه نمره افسردگى براى كروه آزمايش در يِش آزمون برابر با سM/Fq شده است كه يִ از اجراى مداخله سايكودرام در يس آزمون نمره افسردكى VI/ ·r شده است. تفاوت بين ميانگين نمرات افسرد گى در مرحله يس آزمون بعد از كنترل نمرات بيش آزمون در دو كروه آزمايش و كنترل، معنىدار است (ه) كروهدرمانى سايكودراما در كاهش افسردگى بيماران افسرده بسترى مؤثر است. همجنين همان كونه كه از ستون اندازه اثر (مجذور اتا) بيداست مداخلات مبتنى

جدول ץ تحليل كوورايانس تك متغيره جهت بر رسى اثر مداخله شناختى بر افسردگى

\begin{tabular}{|c|c|c|c|c|c|c|c|}
\hline توان آزمون & اندازه اثر & معنى دارى & $\mathbf{F}$ & مجذوراتكين & آزادى درجه & مجذوروات & منبع تغييرات \\
\hline .1 .9 & $\cdot /$ & .1 & $9 / \cdot 0$ & $099 / 491$ & 1 & $099 / Y 91$ & يِيش آزمون \\
\hline \multirow[t]{3}{*}{$1 / \cdots$} & - $/ A r$ & $\cdot 1 \cdots \cdot 1$ & $1 \cdot M^{E}$ & GYI/IYI & 1 & GYI/IrI & كروه \\
\hline & & & & $\Delta / A Y$ & IV & $99 / 94$ & خطا \\
\hline & & & & & r. & TrMFI & كل \\
\hline
\end{tabular}

بدين معنى كه مداخله كروه درمانى شناختى در كاهش افسردگى بيماران افسرده بسترى مؤثر است. همجينين همان كونه كه از ستون اندازه اثر (مجذور اتا) بيداست مداخله گ گروه درمانى شناختى در كاهش افسردگ درصد مؤثر واقع شده است اين بدان معناست كه

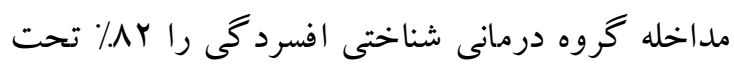
تأثير قرار داده است و موجب كاهش آن شده است.
با توجه به جدول ميانخين ها مشاهده مي شود كه نمره افسردكى براى گرووه آزمايش گرووددرمانى شناختى در ييش آزمون بر ابر با سم/Fq شده است كه يس از اجراى

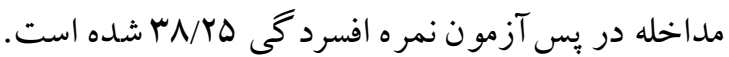
تفاوت بين ميانكين نمرات افسردگى در مرحله يس آزمون بعد از كنترل نمرات بيش آزمون در دو كروه آزمايش و كنترل، معنى دار است (ه هـ • sig ). 
فرضيه r درمان تركيب شناختى - روان نمايشخرى در است. كاهش شدت افسردگى بيماران افسرده بسترى مؤثر

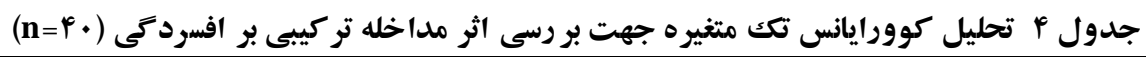

\begin{tabular}{|c|c|c|c|c|c|c|c|}
\hline آزوان & اندازه اثر & معنى دارى & $\mathbf{F}$ & مجذانكين & آزادى درجه & مجذدورات & تغييرات \\
\hline$\cdot / M r$ & $\cdot 1$. & $\cdot / 1 \Lambda$ & $r / . \Delta$ & $r F / N \mid$ & 1 & $r \mu / N \mid$ & ييش آزمون \\
\hline \multirow[t]{3}{*}{$\cdot M^{E}$} & .19. & $\cdot / \cdots \cdot 1$ & $V \cdot N^{k}$ & $119 V / T \Delta$ & 1 & $119 V / r \Delta$ & كروه \\
\hline & & & & $19 / 94$ & IV & YAV/99 & خطا \\
\hline & & & & & r. & G广৭1V & كل \\
\hline
\end{tabular}

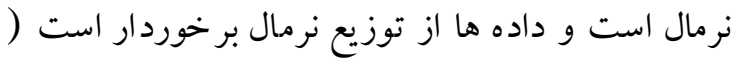
هـ/Sig>) • همجنين براى اطمينان نرمال بودن توزيع

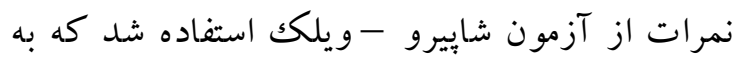
خاطر معنادار نشدن آن در ييش آزمون و يس آزمون مى توان كفت داده ها از توزيع نرمال برخوردار هستند. براى بررسى همخنى واريانسها از آزمون لون استفاده

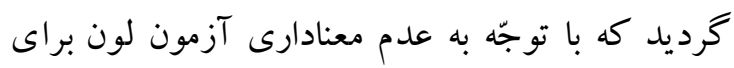

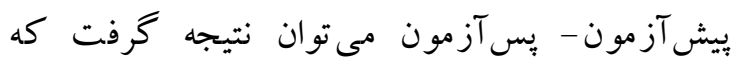

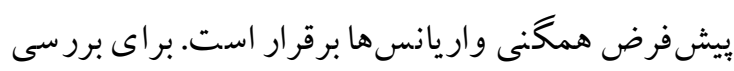

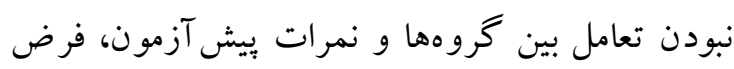

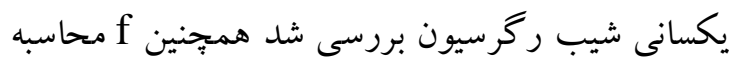

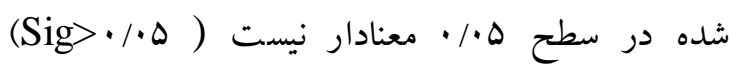
بنابراين شيب رگرسيون در متغير قصد استمداد طلبى دره يكسان است و بين گروهها و بيش آزمون تعامل وجود

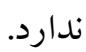
فرضيه F روان نمايشخرى بر ميزان قصد استمداد طلبى بيماران افسرده بسترى مؤثر است.
با توجه به جدول ميانگين ها مشاهده مى شود كه نمره

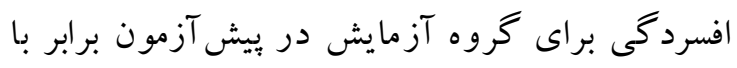

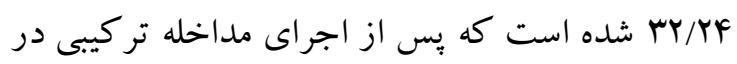
״س آزمون نمره افسردگى بF/YD شده است. تفاوت

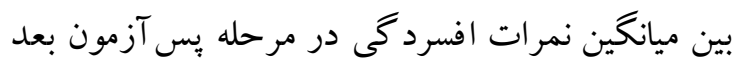

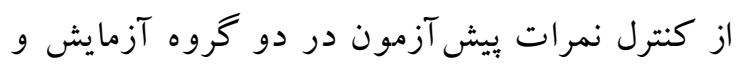

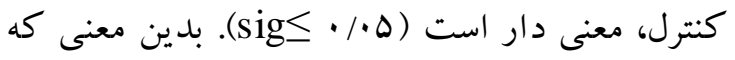
درمان تركيبى (شناختى، روان نمايشگرى) بر ميزان كاهش افسردگى بيماران افسرده بسترى مؤثر است.

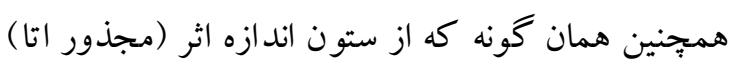

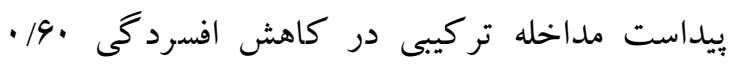
مؤثر واقع شده است اين بدان معناست كه مداخله

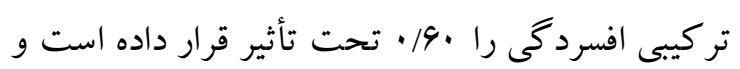
موجب كاهش آن شده است. براى آزمودن نرمال بودن توزيع نمرات از آزمون كولمو گروف - اسميرنوف شاييرو ويلك استفاده كرديد. نتايج اين آزمون نشان مىدهد كه توزيع نمرات

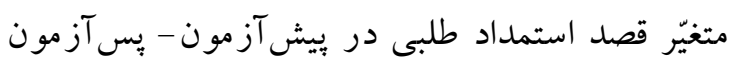

جدول ه تحليل كوورايانس كك متغيره جهت بر رسى اثر مداخله سايكو دراما بر قصد استمداد طلبى مئر

\begin{tabular}{|c|c|c|c|c|c|c|c|}
\hline توان & اندازه اثر & معنى دارى & $\mathbf{F}$ & مجذانكين & آزادى درجه & مجذوروات & منبع تغييرات \\
\hline .1 .0 & . &.$/ 19$ & $r / . \Delta$ & $V r / .9$ & 1 & $V r / .9$ & يِيش آزمون \\
\hline $1 / \cdots$ & . Na & $\cdot / \cdots \cdot 1$ & $9 \Delta / N^{E}$ & rqVI/919 & 1 & rqVI/919 & كروه \\
\hline & & & & $F \Delta / T V$ & IV & V৯৭/rr & خطا \\
\hline
\end{tabular}


كه از ستون اندازه اثر (مجذور اتا) ييداست مداخلات مبتنى بر سايكودراما توانسته است ميزان قصد استمدادطلبى را V9/ · افزايش دهد. اين بدان معناست كه مداخلات سايكودراما قصد استمدادطلبى را N9 تحت تأثير قرار داده است. با نكاهى به ستون توان

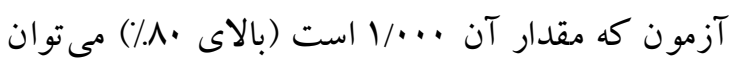
نتيجه كرفت كه ا. نمونه تحقيق از كفايت برخوردار

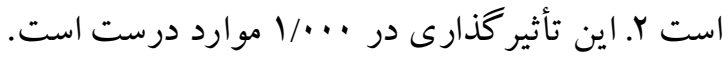
فرضيه ه درمان شناختى بر ميزان قصد استمداد طلبى بيمار ان افسرده بسترى مؤثر است.
با توجه به جدول ميانگين ها مشاهده مى شود كه نمره قصد استمداد طلبى براى گروه آزمايش در يِيش آزمون برابر با IVA/IY شده است كه يس از اجراى مداخله سايكودرام در يس آزمون نمره قصد استمداد طلبى سر/19 شده است. تفاوت بين ميانگين نمرات قصد استمداد طلبى در مرحله يس آزمون، بعد از كنترل نمرات يِش آزمون در دو گروه آزمايش و كنترل، معنى روان نمايشكرى بر ميزان افزايش قصد استمداد طلبى بيماران افسرده بسترى مؤثر است. همجينين همان كونه

جدول و تحليل كوورايانس تكى متغيره جهت بر رسى اثر مداخله شناختى بر قصد استمداد طلبى

\begin{tabular}{|c|c|c|c|c|c|c|c|}
\hline توان & اندازه اثر & معنى دارى & $\mathbf{F}$ & ميانَين & آزادى & مجمهوع & منبع تغييرات \\
\hline$\cdot / \cdot \wedge$ & r/ת & $\cdot 119$ & $F / Y Y$ & $M F / \Lambda I$ & 1 & $|r \Delta G /|$ & يِش آزمون \\
\hline \multirow[t]{3}{*}{.191} & - NG & $\cdot / \cdots$ & $\Delta \Delta / / F$ & $119 \mathrm{~V} / \mathrm{r} \Delta$ & 1 & ו IrD/Tr & تو \\
\hline & & & & Fr/Dq & IV & $V Y F / \cdot \wedge$ & خطا \\
\hline & & & & & $r$. & 9491109 & كل \\
\hline
\end{tabular}

همجنين همان كونه كه از ستون اندازه اثر (مجذور اتا ) بيداست مداخلات شناختى توانسته است ميزان قصد استمدادطلبى را V9/ • افزايش دهد. اين بدان معناست كه مداخلات شناختى قصد استمدادطلبى را N9/ تحت تأثير قرار داده است. فرضيه 4 در مان تر كيبى (شناختى، روان نمايشخرى) بر ميزان قصد استمد اد طلبى بيماران افسرده بسترى مؤثر

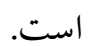

با توجه به جدول ميانگين ها مشاهده مى شود كه نمره قصد استمدادطلبى براى گروه آزمايش در يِيش آزمون برابر با VI/199 شده است كه بِ از اجر ایى مداخله در

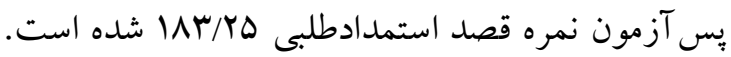
تفاوت بين ميانگين نمرات قصد استمداد طلبى در مر حله يس آزمون بعد از كنترل نمرات بيش آزمون در دو كروه آزمايش و كنترل، معنى دار است (ه./ sig). بدين معنى كه درمان شناختى بر افزايش قصد استمداد طلبى بيماران افسرده بسترى مؤثر است.

\begin{tabular}{|c|c|c|c|c|c|c|c|}
\hline توان & اندازه اثر & معنى دارى & $\mathbf{F}$ & مجذانكين & درادى & مجذورات & منبع تغييرات \\
\hline$\cdot 1 \cdot 1$ & $\cdot / Y Y$ & $\cdot 1 \cdot 1$ & $r / \cdot \Delta$ & $\mid F q V Y / \cdot r r$ & 1 & IFQVY/.rY & بيش آزمون \\
\hline$\cdot \mathrm{NA}$ & .101 &.$/ \cdot 1$ & $I V / M^{E}$ & GFIV/FT & 1 & $G F I V / A T$ & كروه \\
\hline
\end{tabular}


rMI/Ar

iv.

$9 \Lambda \cdot 1 / 99$

خطا

استمداد طلبى بيماران به افسرده بسترى مؤثر است.

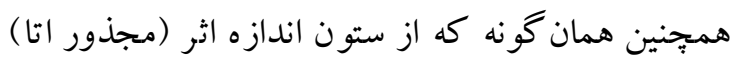
بيداست مداخلات تركيبى توانسته است ميزان قصد استمدادطلبى را اله/• افزايش دهد. اين بدان معناست

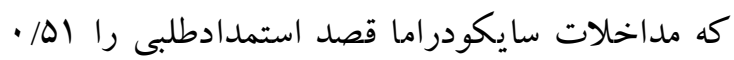
تحت تأثير قرار داده است تحليل مانووا براى به دست آوردن تفاوت بين سه گرووه مداخله
با توجه به جدول ميانگين ها مشاهده مى شود كه نمره

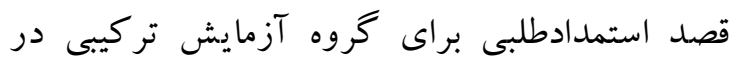

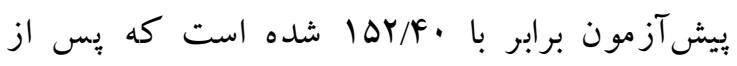

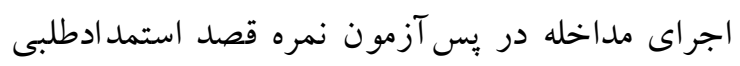
 استمداد طلبى در مرحله يّآزمون بعد از كنترل

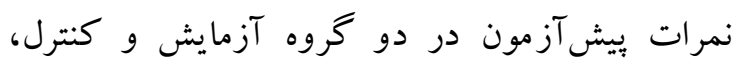
معنى دار است (ه •/ sig تركيبى (شناختى، روان نمايشخرى) بر افزايش قصد

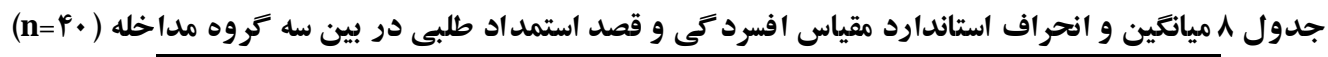

\begin{tabular}{|c|c|c|}
\hline ميانكين (انحراف استاندارد) & كروه & متغير \\
\hline$(r \mid / F) \backslash Q / Y \Delta$ & سايكو دراما & \\
\hline$(\mid r / F) r a / / V$ & 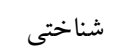 & افسرد \\
\hline$(r Y / Q) Y F / H Y$ & 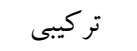 & \\
\hline ميانغين(انحراف استاندارد) & 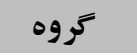 & متغير \\
\hline$(V V / Y I))(99 / Y \Delta$ & سايكودراما & قصد استمداد طلبى \\
\hline$(K T / \Delta F) \backslash \Lambda T / M V$ & 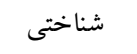 & \\
\hline$(\Delta F / Y I) \backslash \Lambda F / K Y$ & تر كيبى & \\
\hline
\end{tabular}

جدول 9 نتايج تحليل واريانس جند متغيرى براى مقايسهى سه كروه در بس آزمون متغير افسردكى و قصد استمداد طلبى

\begin{tabular}{|c|c|c|c|c|c|c|}
\hline Sig & $\mathbf{F}$ & Ms & Df & Ss & متغير ها & تغنييرات \\
\hline$\cdot /$. & $r F / \| F \Delta$ & 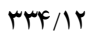 & $r$ & rIVN/.9 & افسرد & كروه \\
\hline
\end{tabular}

$(n=\varphi \cdot)$

سايكودر ا

\begin{tabular}{|c|c|c|c|c|c|c|}
\hline.$/ . F$ & $r \mid / r \Lambda$ & $1 \cdot 19 / 4 \pi$ & $r$ & $999 / .9$ & قصد استمد اد & كروه \\
\hline
\end{tabular}

نتايج

ما، شناختى و تر كيبى در بِ آزمون قصد استمداد طلبى

تفاوت معنادارى دارند؛ يعنى يكى از مداخله ها اثر

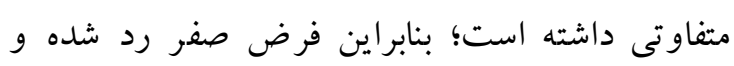

فرض خلاف تأييد مى شود مىشود ( هـ/ • > Sig).
تحليل واريانس جنّ متغيّرى براى مقايسهى سه گروه در پِ آزمون متغيّر وابسته افسردگى و قصد استمداد طلبى نشان داده شده است. با توجّه به اطلاعات جدول نتيجه گرفته مىشود كه فرض صفر در مورد متغيّر وابسته قصد استمداد طلبى رد شده است و ورى خروه 
قصد استمداد طلبى داشته از آزمون تعقيبى توكى

براى اين كه بدانيم از بين سه مداخله در سه گرووه استفاده شد. متفاوت كدام يكك اثربخشى بيشترى جهت افزايش ايش بـن

\begin{tabular}{|c|c|c|c|c|c|}
\hline معنادارى & خطا & تفاوت ميانكين & كروه & كروه & متغير وابسته \\
\hline.$/ . r$ & $r \cdot / \cdot r$ & $1 \cdot \pi r$ & تركيبى & سايكودرام & \multirow{4}{*}{ پِ آزمون } \\
\hline.$/ .1$ & $r \cdot / \cdot r$ & $1 r / 9$. & شناختى & & \\
\hline.$/ . r$ & $r \cdot / \cdot r$ & $-11 / \pi r$ & سايكودرام & تركيبى & \\
\hline$\cdot / r$ & $r \cdot / \cdot r$ & $-1 \Delta / 4$ & شناختى & & \\
\hline
\end{tabular}

است. در تبيين اين يافته مى توان گفت سايكودراما يكك فعاليت گروهى است و در اجراى هر گونه فعاليت كروهى افرادى در فرايند اصلى آفرينش درگيرند و وان

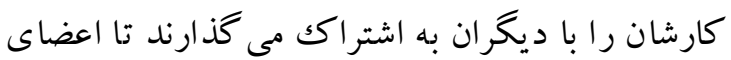
كروه نيز بتو انند درباره كارشان هم در خلان

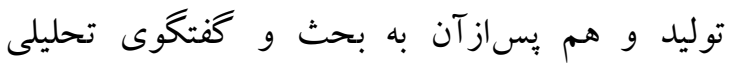

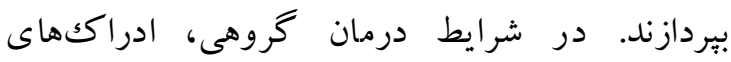
مخدوش، نارسايى ارتباطى، باسخهاى عاطفى نارسا،

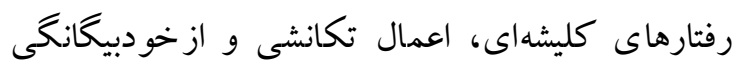
بررسى و تغيير داده مىشود و به نظر مى آيد كه عامل اصلى تأثير گذارى سايكودرام بر كاهش افسردگى نى نيز

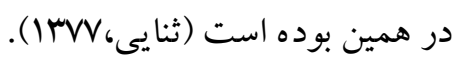

همجنين مداخله شناختى در كاهش افسردكى بيماران بسترى افسرده مؤثر بوده است. اين يافته با تحقيق

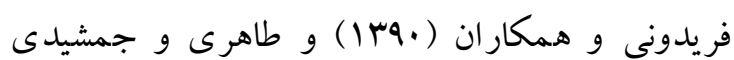
فرد، ویم|؛ نظرى و اسدى، •وسا؛ صالح زاده،

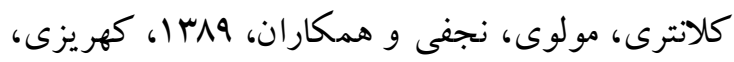

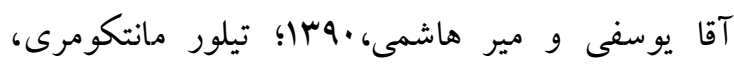

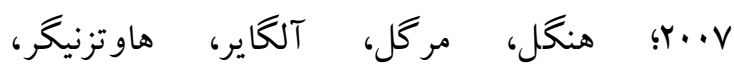

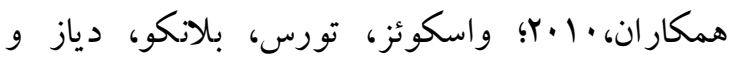

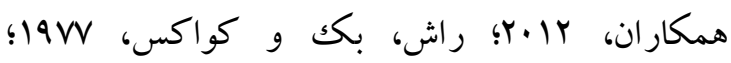

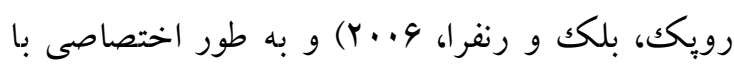
روش مايكل فرى فرى (1999) وتحقيق مك درموت
با توجّه به يافته هاى حاصل از آزمون تعقيبى توكى و با

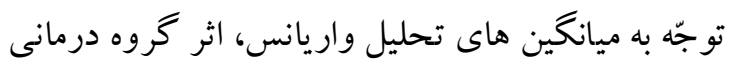
تركيبى و شناختى تفاوت معنادارى ندارد؛ اما گروه

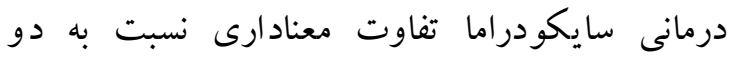
مداخله در افزايش قصد استمداد طلبى بيماران افسرده دارد و اين تفاوت با توجّه به ميانگين ها و تفاوت ميانكينها به نفع درمان سايكودراما است. لذا درمان سايكودراما از درمان شناختى و تركيبى در افزايش قصد استمداد طلبى بيماران افسرده اثربخشتر بوده است. همجِنين با توجّه به اطلاعات جدول نتيجه كرفته

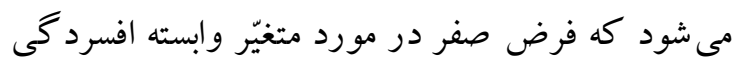

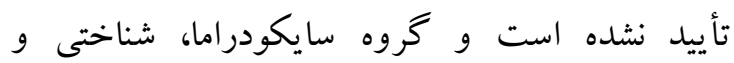
تركيبى در بـ آزمون افسردگى تفاوت معنادارى دارند؛ يعنى هر سه مداخله اثر متفاوتى داشتند؛ بنابراين فرض صفر رد شده و فرض خلاف تأيد مىشود . $(\operatorname{Sig}>\cdot / \cdot \Delta)$ اين مطالعه نشان داد كه گرووه درمانى سايكودراما در كاهش افسردگى بيماران بسترى افسرده مؤثر بوده

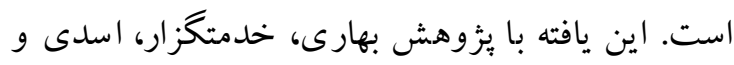

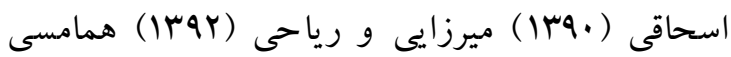

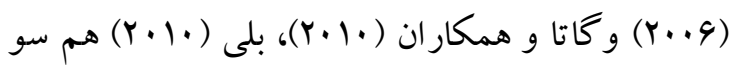


سايكودراما تلقى مى شود. يكى از مفاهيم اصلى در

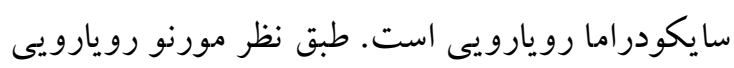
به معناى با هم بودن، ملاقات يكديخر ، ديدن و مشاهده كردن، احساس كردن، متحد شدن،عقب نشينى كردن و دركك يكديخر است. همجنين از طرفى ديخر با تحقيق اسجومروس (11) نيز هم سو است. از سوى ديخر درمان شناختى بر افزايش قصد استمداد طلبى بيماران افسرده بسترى مؤثر بوده است. در تبيين اين يافته نظريه اقدام معقول با قاطعيت اظهار مىدارد كه تنها علت فورى براى هر رفتارى نيّت فرد براى وارد

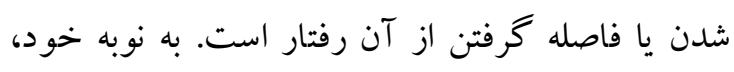
اين نظريه اظهار مىدارد كه نيّات را دو مؤلفه تعيين

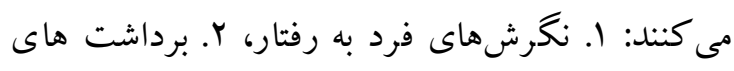
فرد از فشارهاى اجتماعى يا هنجارهاى ذهنى براى وارد

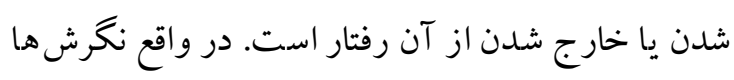
و باورهاى فرد در قصد او تأثير به سزايى دارد.يس در بحث قصد استمداد طلبى مى تو ان نتيجه گرفت كه تغيير

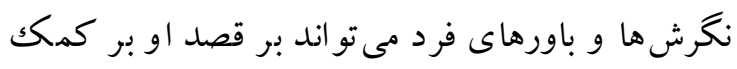
خو اهى اثر كذار باشد. يافته ديخرى نشان داد كه درمان تركيبى (شناختى،

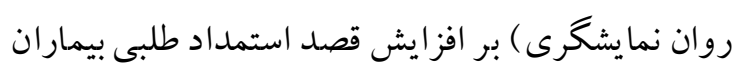
بسترى افسرده مؤثر بوده است. در تبيين اين يافته مىتوان جنين كفت كه طبق نظر ويلسون شناخت درمانى در حل مشكلات بين فردى و بهبود مهارت هاى اجتماعى اثربخشى داشته است. بنابر اين مى توان انتظار

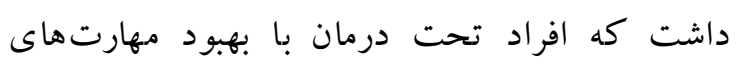
اجتماعى بيشتر درصدد قصد استمد اد از ديخران بر آيند

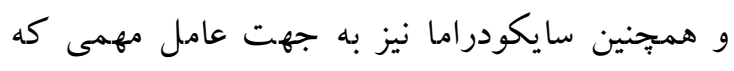

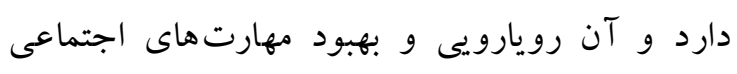
است تر كيب اين دو بر قصد استمدادطلبى اثر كذار بوده

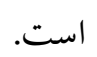

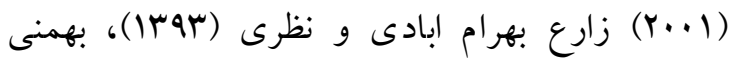

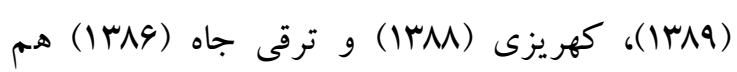
سويى دارد. در تبيين اين يافته مى توان كفت الخوى

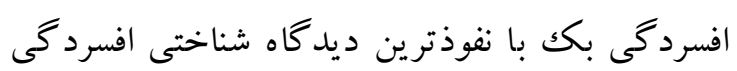

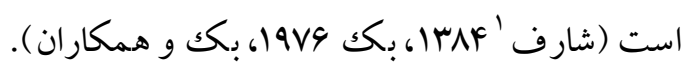

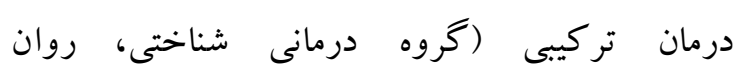
نمايشخرى) بر ميزان كاهش افسردگى بيماران افسرده بسترى مؤثر بوده است. تحقيقات معدودى به تركيب

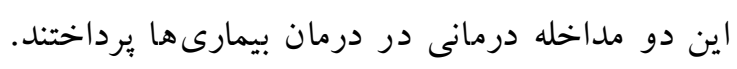

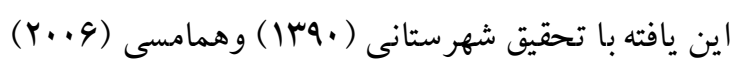

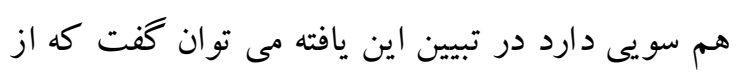

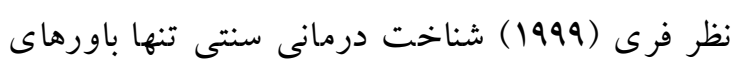
فرد را تغيير مى دهد در حالى كه باورهاى هيجانى

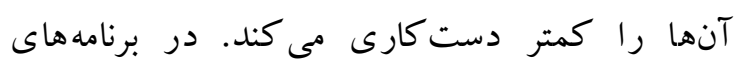

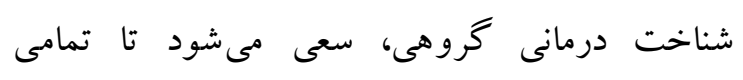

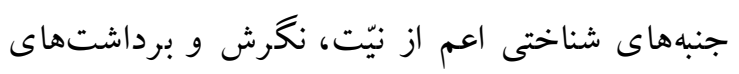

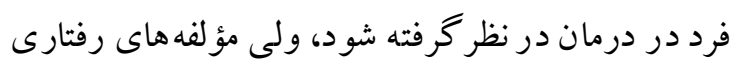

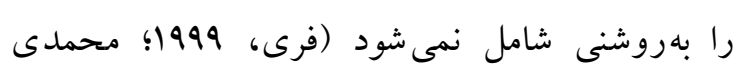

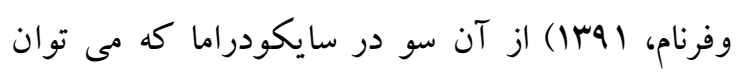

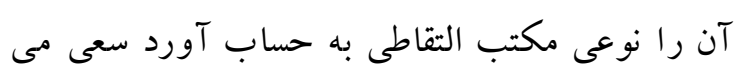
شود تا فرد با ايفاى نقش درباره مسأله اش و نه صرفاً

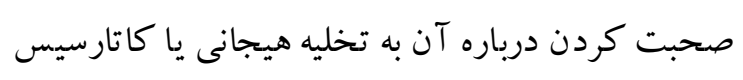

دست يابد كه موجب بهبودى و شفاى فرد مى شود. مداخله روان نمايشگرى بر ميزان افزايش قصد استمداد

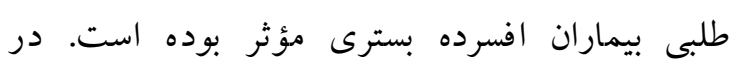

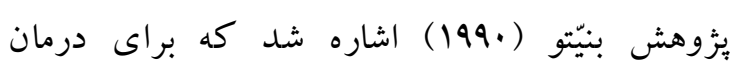
افسردگى بايد مداخلات، انتظارات بِاسخ منفى ديخران

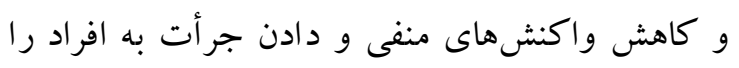

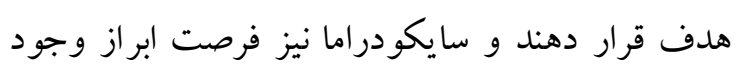

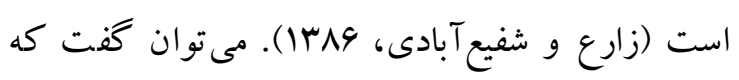
در قصد استمدادطلبى تعامل اجتماعى مهمترين هسته وبله 
اغلب به روابط اجتماعى و مهارت هاى ميان فردى متكى است جنين نتيجهاى قابل تأييد است (ريج ووده،

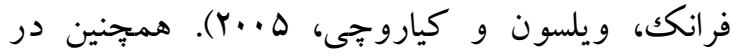

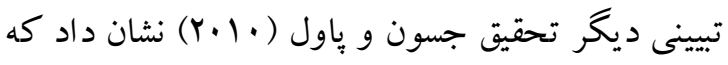
عامل مهم و اثر گذار در قصد استمدادطلبى تمايز يافتكى است و اين مقوله يافته بسيار مهمى است كه وله مى تواند تأكيد بيشترى بر اين يافته و تأييد آن داشته

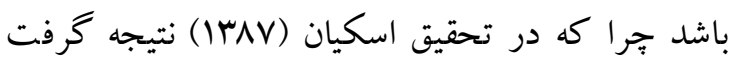

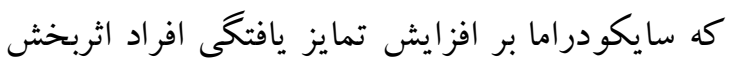
بوده است. يس مى توانيم نتيجه بخيريم كه طبق اين

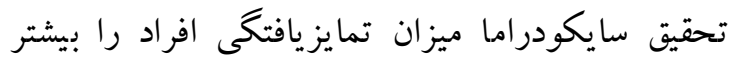

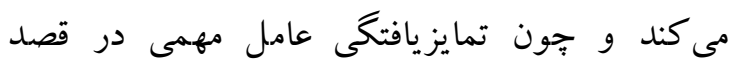

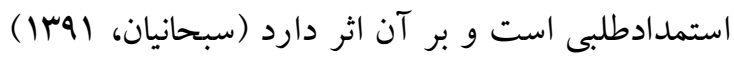

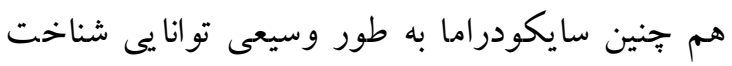
اجتماعى افراد را افزايش مى دهدئ (لى و همكاران،

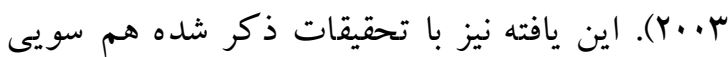

\section{نتيجه كيرى}

در اين يزٔوهش اثر بخشى سايكودراما و گرووه درمانى

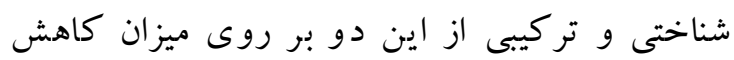

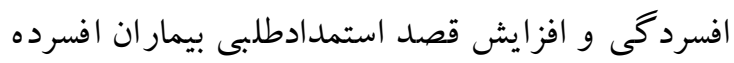
مورد بررسى قرار گرفت كه نتايج نشان داد كه هر سه ونه درمان اثربخش بودهاند. در حقيقت نتايج نشان دادند كه كاهش معنادارى در افسردگى و افزايش معنادارى در ميزان قصد استمدادطلبى شركت كنندگان، بعد از اجراى هر سه مداخله وجود داشته است. همجنين

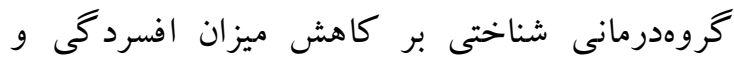
سايكودرام بر افزايش ميزان قصد استمداد طلبى بيماران اثر كذارى بيشترى داشته اند. از جمله محدوديت هاى اين بزوهش عدم همكارى برى

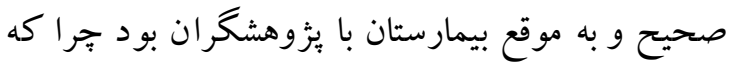

در بررسىهاى بيشتر اثربخشى بيشتر بر كاهش

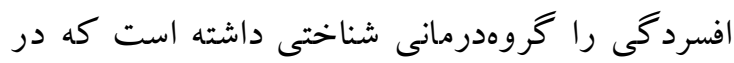
تفسير آن ابتدا مى توان به اين اشاره داشت كه بسيارى

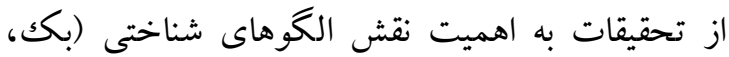
199V

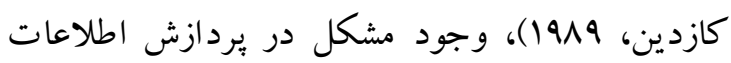

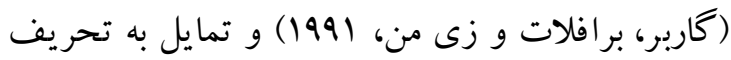

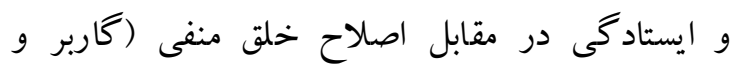

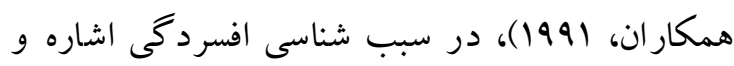
تأكيد داشتهاند. همجنين مداخلاتى كه بر بازسازى شناختى تأكيد دارند در تو انا ساختن بيمار ان براى مقابله و درمان و بيشخيرى از افسردگى بسيار مفيد مىباشند

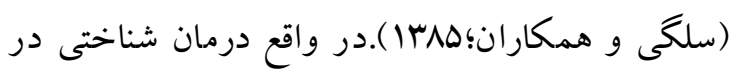
افسردگى بر تمايل منفى در فرايند اطلاعات كه نتيجه

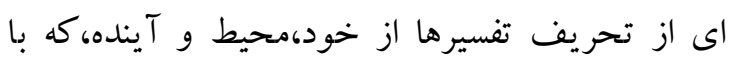

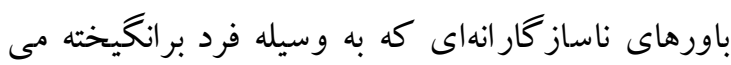
شود،ارتباط دارد، تأكيد مى كند. (هالون، 1911). (بكك

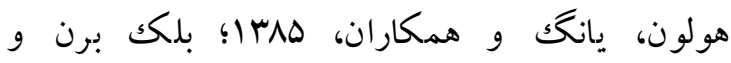

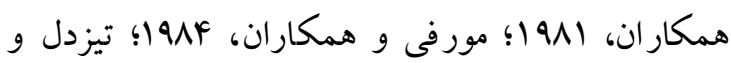

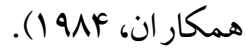
همجِنين در بررسى هاى بيشتر اثربخشى بيشتر بر افزايش قصد استمداد طلبى را مداخله سايكودراما داشته است.در تبيين اين يافته مىتوان گفت كه رويكرد روان

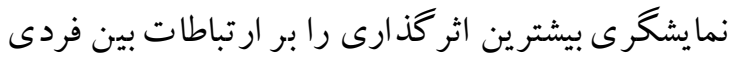

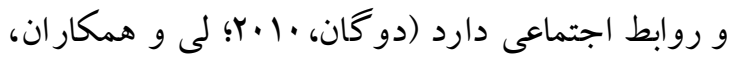

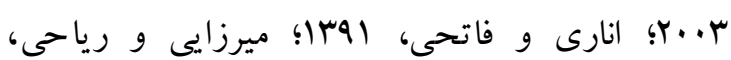

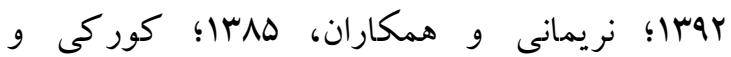
همكار ان، • هץr) و از آنجايى كه قصد استمدادطلبى به طور عمو مى اشاره به رفتار فعالانه و جستجوى كمكك از ديخران است و همجتنين به برقرارى ارتباط با افراد ديخر به منظور به دست آوردن بينش و حمايت

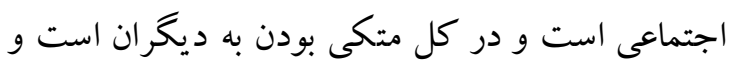


Amraei Majid. (1389). Theather thrapy on the path of evolution. Tehran: Dangeh Publications. [in Persian]

Anari, Asieh; Fatehi, Mohammad. (2013). Reduced social shyness in adolescents using psychosis. Proceedings of the first congress of psychodrama in Iran Tehran: University of Welfare and Rehabilitation. [inPersian]

Bahari, Farshad, Bani Assad, Mohammad Hassan, Servant Hossein and Es'haghi, Faezeh. (2012). The Effect ofPikkodrama on the Rate of Major Depression and General Health of Depressed Patients Under Treatment. Clinical Psychology and Consultation of Ferdowsi University of Mashhad. Number 2.7-69. [in Persian]

Bahmani, B (2010). Ontological Cognitive Therapy and Educational Therapy Cognitive Therapy in Patients with Breast Cancer. Evolutionary

Psychology. Journalof Psychiatry, 2003, 232-213. [in Persian]

Beck AT, Rush AJ, Shaw BF, Emery G. (1979). Cognitive therapy of depression. New York: Guilford.

Beck, AT. (1976). Cognitive Therapy and the Emotional Disorders. New York:International Universities Press

Blackburn IM, Bishop S, Glen AIM, Whalley LJ, Christie JE(1981). The efficacy of cognitive therapy in depression: A treatment trial using cognitive therapy and pharmacotherapy, each alone and in combination. Br J Psychiatry. 139: 181-189.

Blatterner, Adam (1996). Deproduction: Psychotherapy with theatrical techniques (Theatrical). Translator:Hassan Haghshenas and Hamidashkani. Tehran: Growth Publishing House. 1383. [inPersian]

Cepeda-Benito, A., \& Short, P. (1998). Selfconcealment, avoidance of psychological services, and perceived likelihood of seeking professional help. Joumal of Counseling Psychology, 45, 58-64. doi: 10.1037/00220167.45.158.

Ciarrochi, J., Deane, F. P., \& Anderson, S. (2002). Emotonalintelligence moderates the relationship between stress and mental health. Personality and IndividualDifferences, 32, 197- 209.

Clarke, David and Farbom, Kirstoffer. Knowledge and Practical Approach to Cognitive-Behavioral

$$
\begin{aligned}
& \text { بيشتر زمان يكك محقق به جاى برداختن به اصل } \\
& \text { موضوع يزوهش صرف روند ادارى و راضى كردن }
\end{aligned}
$$

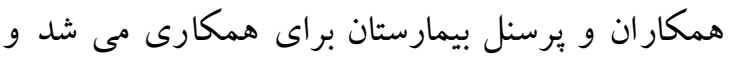

$$
\begin{aligned}
& \text { به دليل عدم همكارى بيمارستان اجراى بيخيرى } 9 \text { ماهه } \\
& \text { وجود نداشت كه در تحقيقات بعد بيشنهاد مى كردد. } \\
& \text { همجنين به جهت كم بودن تعداد بيماران مورد نظر در }
\end{aligned}
$$

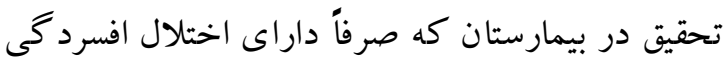

$$
\begin{aligned}
& \text { عمده باشند و معيارهاى خروج كه در فصل ب به آنها }
\end{aligned}
$$

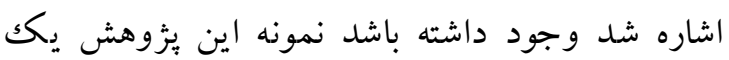

$$
\begin{aligned}
& \text { نمونه در دسترس بوده است كه بهتر است شرايطى } \\
& \text { فراهم گردد تا آزمودنى ها از لحاظ متغيرهاى ناخواسته بوده }
\end{aligned}
$$

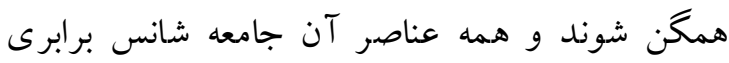

$$
\begin{aligned}
& \text { براى انتخاب شدن داشته باشند. اين شيوهاى است كه به } \\
& \text { ما اطمينان مى دهد كه همه اعضاى يكك جامعهى آمارى } \\
& \text { شانس مساوى براى انتخاب شدن دارند و در نهايت } \\
& \text { مو جب مى شود كه از خطاى سيستما تيك بيرهيزيم. }
\end{aligned}
$$

$$
\text { سباسگزارى }
$$

در بايان از همه كسانى كه ما را در اجراى اين بثزوهش

$$
\text { يارى كردند تشكر و قدردانى مى نماييم. }
$$

\section{Refrences}

Ajzen, I. (1996).The Theory of Planned Behavior: A Bibliography. [Internet] (Receive in 2006/15/6).

Ajzen, I. (2002). Constructing a TPB questionnaire: Conceptual and methodological considerations. University of Massachusetts Amherst, Office of Information Technologies. Retrieved November American psychiatric association (2000). diagnostic and statistical manual of mental disorders.washington,DC:Autor.

Ames, R. (1983). Help_seeking and echievement orientation perspectives from attribution theory. In; B. M. depaulo, A. Nadler, J. d. Fisher (Eds). New direction in helping, (Vol) 2: help_seeking, 165-186. New York: academic Press. 
Therapy. Translator: Hossein Kaviani. Tehran: Fars Publications. 1380. [in Persian]

Cohen,B.(1999).Measuring willingness to seek help.joumal of social science research,26,67-82.

Crass, J. Psychological Disorders. Mahmoud Mansour and Pereirahkh Attorney. Tehran: GrowthPublication 1986. [in Persian]

Curie, Gerald (1937). Group Counseling Theories and Methods. Translator. Faezeh Asgari et al Tehran: ShabnamPublishing., 1391. [inPersian]

Deane, F. P, Wilson, C. J., \& Ciarrochi, J. (2001). Suicidal ideation and help-negation: Not just hopelessness or prior help. Journal of Clinical Psychology, 57, 1-14.

Dobson, K.S. (Ed.) (2000). Handbook of CognitiveBehavioral Therapies. 2"'n ed. New York: Guiiford Publications.

Dogan,Turkan,(2010).The effects of psychodrama on young adults attachment styles.journal of the arts in psychotherapy37(2010)112-119

eek psychiatric help for depression: A representative population survey applying the Theory of Planned Behavior. Psychological Medicine, 39,1855-1865.

Eskyan, Parasto; Snaei Zakir, Baqir; Navobinejad, Shokouh. (2008). The study of the effect of pseudo-smoking on increasing the differentiation of the individual from the main family in high school girl students in district 5 . Journal of Consultative Research, No. 25, pp. 27-42[in Persian]

Fereidouni, Shapour et al (2012). The Effect of Cognitive Therapy on the Rate of Depression and Academic Performance of Controlled and Self-Leamed Students. Journal of Cognitive and Behavioral Sciences. Number 2, pp. 91-104. [in Persian]

Free,M.L. \& andoeiT.P.(1989).Biological and psychological process in the treatment and maintenance of depression clinical psychology.Review.9,653-688.

Free,ML.(1999) Cognitive Therapy In Groups For Practice.Guidelines and Resources Book.

Frey, Michael (1999). Practical Guide to Cognitive Therapy Group. Translator. Masoud Mohammadi and Robert Farnam Tehran: Growth Publishing, 1391.. [in Persian]

Garber,J,kriss,M.R.,Koch,M.,\&Rehm,L.P.,\&Sharp, R.N.(1996).Strategies for children depressionin M.A.Reineke,F.M.Dattiio,\&A casebook for clinical practice (pp.103-123). New Yorkj: Guilford Press.

Gattaa, Michela. Laraa,Dal Zotto. Larab,Del Col Andreac, Spoto.(2010).Analytical psychodrama with adolescents suffering from psychobehavioraldisorder:Short-term effects on psychiatric symptoms,journal of The Arts in Psychotherapy 37, 240-247.

Golestanian, Azita et al (2013). Comparison of the Effectiveness of Cognitive-Behavioral Therapy and Psycho-Therapy on Invalid Attitudes and Creation of Prisoners Juveniles with Depression Symptoms. Collection of Articles of the First Congress of Psychodrama in Iran Tehran: Welfare and Rehabilitation University.. [in Persian]

Hamamci, Z (2006). Interacting psychodramand cognitive behavioral therapy to treat moderate depression. The Arts in Psychotherapy. 33 (4): 199-20.

Henkel, V. Mergl R.ALLGAIER, ak. Hautzinger, M.\&et al (2010). Treatment of atypical depressionpost-hoc analysis of a randomized controlled study testing the efficacy of sertraline and cognitive behavioural therapy in mildy depressed outpatient:European psychiatry: 25 (8):491-498

Hollon.SD\& Beck AT (2004). Cognitive and cognitive-behavioral therapies. In Garfield

Houghton et al (1942). Cognitive therapy: A Practical Guide to the Treatment of Psychiatric Disorders. Translator: Habibollah Ghasemzadeh Tehran: Arjmand. 2010. [in Persian]

Islamic Consultative Research Center (1394). Publication of the 2008 World Health Organization report. Available at: http $/ /$ rc.majlis.ir/en/news/show/.. [inPersian]

Kahrizzi, Ehsan and Agha Yousefi, Alireza and Mir Hashemi, Malek (2011). Effect of cognitive group therapy on Michael Frey's method of reducing the depression of prisoners. Thinking and Behavior. No. 22. p. 21-40. [in Persian]

Kelly, A. E. \& Achter, J. A. (1995). Selfconcealment and attitudes toward counselling in university students. Journal of Counseling Psychology, 42, 40-46.

Kendall, EC., Cantwell, D., \& Kazdin, A. E. (1989). Depression in children and adolescents: Assessment issues and parkinsoriian symptoms,tardive dyskinesia,and associated 
factors in child and adolescent psychiatric patients.American Journal of psychiatry, 148, 1322-1328.

Kipper, D. A., \& Hundel, J. (2003). A survey of clinical reports on the application of psychodrama.Jomal of Group Psychotherapy,psychodrama,\& Socimetry,17,141-157

Korki, Maryametal (2011). Psychosocial Effects on Improving Social Skills and Reducing Intemet Addiction in Female Students. Iranian Journal of Psychiatry and ClinicalPsychiatry. Number.4668.. [in Persian]

Lambert, K. G. (2006). Rising rates of depression in today's society: Consideration of the roles of effortbased rewards and enhanced resilience in day-to-day functioning.

Lee.A. \& Hankin. B.L. (2009). Insecure attachment, dysfunctional attitudes,and bw self-esteem predicting prospective symptoms of depression and anxiety during adolescence.journal of clinical child \&adolescent psychology, 38 (2), 219-231

Mcculloch, j, Prins. H. A. (1975). Sings of stress, the social problems associated wih psychiatric illness London, collinclear type press.

Miller,R.C. \& Berman,J.S.(1983).The efficacy of cognitive behavio therapies:A quantitative review of the research evidence psychological Rulletin,94,39-53

Mirza'i, Jafar and Riahi, Shahram(1392). A review of psychoanalytic studies: systematic research and meta-analysis (1993-2013). Proceedings of the first congress of psychodrama in Iran Tehran: University of Welfare and Rehabilitation. [in Persian]

Murphy, G. E, Simons, A. D., Wetzel, R. D., \& Lustman, P. J. (1984). Cognitive therapy and pharmacotherapy. Singly and togetherin the treatment of depression.Arch Gen Psychiatry. 84; (41): 33-41. Neuroscience \& Biobehavioral, $30(4), 497-510$.

Narimani, Mohammad; Baybandrand, Ismail and Rajabi, Suran (2006). Effectiveness of psychoanalyzer on improving the social skills and selfesteem of dyskexic students. Available at www.sid.ir.. [inPersian]

Nazari, Ali Mohammad and Asadi, Masoud (2009). The Study of the Effect of Cognitive Group Therapy on the Depression of Students. Journal of Knowledge and Health. Number 1. 51-53. [inPersian]

Newman, R. S. (1991). Children's help-seeking in the classroom: The role of motivation factors and atitudes. Journal of Educational Psychology. 82: 72-86.

Newman, R. S. (1998). Children's help_seeking during problems solving: Influances of personal and contextual achievement goals. Journal of EducationalPsychology, 90,644-658.

Oei,T.P.S. \& Free,M.L.(1995) does cognitive behavior therapy validate cognitive models of mood disorder?A review of the empirical evidence international joumal of psychology. 30, 145-179.

Reinecke,M.A.,Ryan,N,\&DuBoise,D.(1998).Cognit ive-behavioral therapy of depression and depressive symptoms during adolescence:A reviw and meta-analysis.Joumal of the American Academy of Child and Adolescent Psychiatry.v.37.26-34.

Riahi, Shahram et al (1392). The psychosocial effect of screening on the negative symptoms of admitted schizophrenic patients. Proceedings of the first congress of psychodrama in Iran. Tehran: University of Welfare and Rehabilitation. [inPersian]

Rickwood, D., Deane, F. P., Wilson, C. J., \& et al (2005). Young people's helpseeking for mental health problems. AeJAMH; 4 Suppl: 1-34.

Robinson, L. A., Berman, J. S. \& Neimeyer, R. A. (1990).Psychotherapy for the treatment of depression: a comprehensive review of controlled outcome research.Psychological Bulletin,108,30-49.

Rush,A.J,Beck,A.T,Kovacs,M, \&Hollon,S.(1977).Comparative efficacy of cognitive therapy and thermotherapy in the treatment of depressed outpatients.cogn ther res.77(1):17-37

Ryan, A. M., Gheen, M. H. Midgley, C. (1998). Why do some students avoid asking for help? An examination of the interplay among students academic efficacy, teacher's socialemotional role, and classroom goal structure. Journal of EducationalPsychology. 90:528-538.

Ryan, A. M., Pintrich, P. R., Midgley, C. (2001). Avoiding seeking help in the classroom: who and why? Educational psychology review 13(3):93-114. 
Ryff.D.C(1989).Happiness is every thing or is it/exploration on the meaning of psychological well being journal of personality and social psychology. v(57).p:1069-1081.

Salehzadeh, Maryam Kalantari, Mehrdad Molavi, Hossein Najafi, Mohammad Reza et al. (2010). Effect of cognitive-behavioral group therapy on depression in patients with epilepsy resistant to epilepsy (with emphasis on inappropriate epilepsy attitudes). Science scores Cognitive, 12 (2): 68-51. [in Persian]

Salgi, Zahra and Hashemian, Kianoush and Saeedipour, Bahman (2006). The Effect of Group Cognitive Therapy on Depression Depression in Patients with HIV-positive Patients. Psychological Studies, Faculty of Educational Sciences and Psychology, Alzahra University, Volume 3, Number 4, Winter. [in Persian]

Schomenus, G., Matschinger, H., \& Angermeyer, M. C. (2009a). Atti-tudes that determine willingness to $\mathrm{s}$

Shahrazestani, Maliheh et al (2014) The Effect of Training on the Cognitive-Psycho-Integrative Compilation Approach on Correction of Ineffective Communication Beliefs in Married Women. Female Joumalism in Culture and Arts. Number.283-296.. [inPersian]

Sharf. R (2004). Theories of Psychotherapy \& Counseling: Concepts and Cases. Pub Sengage Learning.

Sharp, L. K., \& Lipsky, M. S. (2002). Screening for depression across the lifespan: a review of measures for use in primary care settings. American family physician, 66 (6), 1001-8.

Sobhaniyan, Fatemeh (2012). The relation between self-differentiation and the purpose of seeking women in Tehran. Master's Degree, Islamic Azad University, Science and Research Branch of Arak.. [in Persian]

Taheri, Afsaneh and Jamshidifar, Zahra (2007). Applied Psychology. First Edition No. 3.51-51. [in Persian]

Taybr,TL.(2007).Can cognitive-behavioral therapy increase self-esteem among depressed adolescent? A systematic review.children and youth services Review,29(7):833-829.

Teasdale JD, Scott J, Moore RG, Hayhurst H,Pope M, Paykel ES. 2001. How does cogni-tive therapy prevent relapse in residual de-pression: evidence from a controlled trialJ.Consult. Clin. Psychol69:347-57.

Tragedayah, Sadegh. (2007). The CognitiveBehavioral Frey Group Counseling Approach to Reduce Depression in Tarbiat Moallem University Students. Available at: WWW.MSRT.IR[in Persian]

TredwellW.T.Kumar,V.K.\&Wright,J.H.(2002)Enri ching psychodrama through the use of cognitive behavioral therapy techniquse.The international journal of action methodspsychodrama, skill training and role playing,55.55-66

Vazquez,FLTorres,A.Blanco ,V.Diaz ,O.\& et $\mathrm{al}(2012)$.Comparis on of relaxation training with a cognitive-behavioural intervention for indicated prevention of depression in university students:A randomized controlled trial.Journal of psychiatric Research:46(11):1456-1463

Ventis, L W. (2002). Depression, Creativity and mental health, performance, psychology in the schools. journal of vocational, psychology voll 2. $304-309$.

Yousefi Loyeh, Majid, Sakhi, Mahdiyeh, Nafisi, Gholamreza and Reisi, Zohreh (2009). The Effect of Learning Happiness on the CognitiveBehavioral Behavioral Approach on General Health and Emotional Intelligence of Students. Available at:www.sid.ir. [inPersian]

Zare Bahram Abadi, Mehdi and Nazari, Tayyebeh (2013). Effect of cognitive group therapy on depression and self-efficacy of women headed by family. Phd dissertation of clinical psychology studies. Number 14-83-97. [in Persian]

Zare, Mehdi Shafiabadi, Abdolah. (2007). Comparison of the Effectiveness of RationalEmotional Group Counseling, Behavioral and Psycho-Consultant Counseling on Increasing General Health and Emotional Expression of Female Patients, Evolutionary Psychology, Iranian Psychologists, No. 1 (2), p. 148-.181[in Persian]

Zeman, sophine. (2003). Mental health and illness in young people. The Ethic of Neuroscience information sheet. 4. 21.27. 